\title{
Using WH-Questions Method in Pantomime Video via Zoom: Improving Students' Writing Skill in Narrative Text
}

\author{
Raymond Willinsky, Cindy Liana, Vontricia Velora, and Sri Ninta Tarigan \\ Universitas Prima Indonesia, Medan, Indonesia \\ cindyliana394@gmail.com
}

\begin{abstract}
ARTICLE HISTORY
Received :19 February 2021

Revised : 20 February 2021

Accepted : 30 March 2021
\end{abstract}

\section{KEYWORDS}

Narrative Text Writing

Pantomime Video

WH-Questions

Classroom Action Research

Online Learning

\begin{abstract}
The purpose of this research is to find out whether pantomime videos of WH-Questions, i.e., who, what, when, where, why, which and how, are able to improve students' narrative text writing ability. Involving students from 10th grade computer network engineering (X TKJ1) of SMK Swasta Imelda Medan, the method used in this research is classroom action research. The action research was conducted in two cycles and analysed two types of data, namely qualitative and quantitative, obtained with instruments of writing test and openended questionnaire. The results of the research show that the obvious improvement is, by using pantomime video as guided, students were able to create a variety of better ways to start a story or narrative. Besides, the students could make sure that they used the appropriate verb tense in their writing. Moreover, the students could widen their vocabulary in describing the action of the mimes in pantomime video. Remembering the online teachinglearning process held in this pandemic era is hindering students' engagement with most English skills, the researchers proved that watching pantomime video via Zoom can significantly heighten students' enthusiasm in learning online and push them to figure out ways, thus using more words, in describing pantomimes than they usually would with traditional lesson instrument of books or written materials.
\end{abstract}

\section{Introduction}

The upgraded form of the education system is used in order that students behave properly and become active in learning, in which a teacher will only be a facilitator in the learning process. Basically, this system requires teachers to replace the old learning processes that tend to be monotonous becoming more creative by adding media to support the learning process, such as adding the visual media like a tape recorder, short video, picture, graph, slide, illustration, chart, etc. (Junaidi et al., 2020; Rahim, 2019).

Video is a media that can be used to teach English writing. By using video as media support in classroom activities, students can be guided to study with high levels of engagement (Yudar, Aditomo, \& Silalahi, 2020). "Video provides information about the eyes and ears, so students can see the actual communication," (Edge, 1993, p. 58). Video can also express language actively, by using video it can seeing language-in-use because students not only hearing the language but also can understand the massage from the expression, emotion, or gestures. It can give most advantages for the teacher who want teach language in class (Harmer, 2001).

In this study, the researcher will apply the pantomime video as teaching media. The reason why researchers choose pantomime video as media support is that pantomime is a unique resource that urges students' participation and knowledge into writing because it drags down the basic ideas of communication; a symbolic movement that everyone has (Aubert, 2005; Derin et al., 2020). This uniqueness is of significant value for the learning process which has been less than optimal due to the Covid-19 pandemic forcing an abrupt change of learning format for students' worldwide (Syafiq et al., 2021).

This study primarily cited and compared with three other researchers who have conducted a similar research in the past to strengthen this research. The first researcher, Deta (2018), conducted a pantomime video in his research give positive feedback in teaching writing the tenth-grade students, by compared the average score of students she gets the score increase 1.24 point. By applying pantomime video as teaching media, it can give positive impact to develop the students' ability in writing, more ever this media can be suitable to teach any kind of text because it will drive students to creative thinking and more imaginative in writing. The second researcher, Raharja (2016), conducted a research by using pantomime video as a means of improving a student's potential in writing ability, especially in narrative text. The researchers found that the pantomime video helps students to organize an idea, which is the hardest part of writing. Because the students just follow the chronology from video as guidance in the writing process. The third researcher, Puspitasari (2017), conducted a research of WHQuestions method on writing narrative text resulting in the improvement of students' narrative writing skills in which the average score of students increased from 58.13 (bad to 
average) in the first cycle to 78.39 (average to good) in the second cycle. The classroom action research is conducted in two cycles, including four stages: planning, action, observation and reflection.

By reflecting on the success of these three previous studies, the researchers feel challenged to try research by applying this method in a different way, by considering the learning system that must be online at this pandemic era. The researchers wanted to find out whether the method of watching pantomime video with $\mathrm{WH}$-questions as guided could provide an increase in students' ability to write narrative text when applied using zoom. Where students are expected to get motivation and high enthusiasm from themselves to improve writing skills, without being directly monitored.

Students ought to master one of the four language skills of listening, speaking, reading and writing. Writing is one of the four basic language skills that is considered essential to students' language learning. By writing, students will be able to express ideas and concepts, improve vocabulary and expand knowledge. According to Richards \& Renandya (2002). the writing skill is the most difficult for students because the writing skill is not only about writing down ideas, but it's also about how to explain ideas then generate them into an acceptable text.

In teaching theories, the teacher has a leading role in improving the potential of students in writing. However, teachers in reality do not have a certain method of teaching writing, which causes students to have a thought of learning. It is just like studying with a textbook making the students feel uninterested in studying. Therefore, the researchers try to find an attractive method that involves students to be more active. In this research, the researchers will apply WHQuestions method by using pantomime video to improve students' writing skills in narrative text.

In the writing process, many texts will produce such as expository, descriptive, persuasive, narrative, recount, report, argumentative, etc. In this study, the researchers expected students to be able to deepen their understanding about narrative writing skill. The reason why the researchers choose narrative text in this study is because narrative text is a genre that describes the chronology of a story about experience in different ways problematically which turns into a resolution. Being easy to study and focusing on developing an idea in the writing process can make students enjoy and be interested in studying. According to (Derwianka, 1995, pp.40), written that "The main function of a narrative text is to entertain, but it is also to teach or nourish and extend the readers imagination"

Furthermore, according to (Scanlan, 2003), narrative text is chronologically structured by a beginning, middle and end of a story. This conveys an attractive message for the reason readers keep reading. It may attract readers in an emotional way by allowing them to interact with obvious things, sometimes conveying unfamiliar plots and characters, with recognizably identified details.

Based on research observation at SMK Swasta Imelda 2020/2021, most issues faced by the students are students' lack of motivation to use English in writing practice, limited vocabulary thus blocking students' creativity, monotonous using of present tense, poorly written structure of text, continuous interpretation word by word, trivial understanding of punctuation, and lack of feedback from the teachers. The reasons why this research is important are, (1) in general, students from SMK Swasta Imelda cannot write English properly, even the students who get high scores in English examination are unable to write in good sentences and take too long time to start expressing their idea into sentences, (2) by watching pantomime video, students may be able to learn. Beside from being fun, pantomime video can increase motivation and can give a great opportunity for developing imagination or an idea in the writing process, (3) WH-question is very effective strategy for students to categorize some idea into the main idea in writing.

\section{Method}

This classroom action research (CAR) was conducted in two cycles, the first cycle has 3 (three) meetings, and the second cycle also designed to have 3 (three) meetings. It uses both qualitative and quantitative data to measure students' narrative writing through the WH-Questions method. The classroom action research is carried out for the online classroom teaching process to solve the problems encountered by students in writing narrative texts.

This research is conducted in SMK Swasta Imelda Medan. The school is located at Jalan Bilal No.52 Medan. The subject in doing this research is tenth-grade computer network engineering (X TKJ1) of SMK Swasta Imelda Medan which has 38 (thirty-eight) numbers of students. The researchers choose this school because this school gives priority in academic knowledge making the researchers become interested in conducting research in this school.

This research uses 3 (three) procedures, such as Identifying the problem, Implementing the action research and doing evaluation. In identifying the problems, the researchers observe the teaching-learning process and provide students with pre-writing tests. When Implementing the action research, This research conduct based on the (Kemmis \& McTaggart, 1988) is following four steps i.e., plan, action, observation and reflection.

Planning activities which include: (1) teaching material, (2) students' personal data (name and scoring), (3) teaching media (pantomime video entitled "Mime First Love"), (4) open-ended questionnaires (google form), and (5) writing tests. Action activities which include: (1) giving writing test I, (2) teaching WH-Questions by using Zoom and Google Classroom (during coronavirus pandemic), (3) giving chance to the students to ask and discuss the poorly understood explanation, (4) explaining students' tests and 
guiding students in doing their tasks, (5) giving writing test II, and (6) giving open-ended questionnaires. Observation activity which is observing students' activities in teachinglearning process. Lastly, reflection activity which is deciding whether cycle II needs to be carried out according to the analysis of the tests and the satisfaction from the researchers.

At the end of the CAR, the researchers conducted an evaluation by collecting data from the writing tests and openended questionnaires to show whether classroom action research is successfully applied or not. The instruments used by researchers in this research are open- ended questionnaires and writing tests. Open-ended questionnaires consist of a few questions which are freely answered by the students about their feeling, opinion, and perception about the situation in teaching-learning process. Writing tests consist of pre-writing test, conducted at the beginning of cycle I, to show students' genuine writing skills; writing test I, conducted at the end of cycle I; and writing test II, conducted at the end of cycle II, to measure students' writing skill improvement.

Table 1. The Scoring Writing Narrative Rubric

\begin{tabular}{|c|c|c|c|c|}
\hline Aspects & 06-Oct & Nov-15 & 16-20 & $21-25$ \\
\hline \multirow[t]{2}{*}{ Reasoning } & Only a few simple ideas & Use simple ideas & Developed ideas & $\begin{array}{l}\text { Well developed, } \\
\text { interesting ideas }\end{array}$ \\
\hline & $\begin{array}{l}\text { Very few supporting } \\
\text { details }\end{array}$ & Some supporting details & $\begin{array}{l}\text { Sufficient supporting } \\
\text { details }\end{array}$ & Many descriptive details \\
\hline \multirow[t]{3}{*}{ Communication } & Unclear purpose & $\begin{array}{l}\text { The purpose is } \\
\text { somewhat clear }\end{array}$ & Clear purpose & $\begin{array}{l}\text { Clear purpose and } \\
\text { engaged the reader }\end{array}$ \\
\hline & Limited vocabulary & Some vocabulary & $\begin{array}{l}\text { A wide variety of } \\
\text { vocabulary }\end{array}$ & Extensive vocabulary \\
\hline & Simple sentences & $\begin{array}{l}\text { A limited variety of } \\
\text { sentences }\end{array}$ & A variety of sentences & $\begin{array}{l}\text { A wide variety of } \\
\text { sentences }\end{array}$ \\
\hline \multirow[t]{2}{*}{ Organization } & $\begin{array}{l}\text { No clear beginning, } \\
\text { middle or end }\end{array}$ & $\begin{array}{l}\text { Some evidence showing } \\
\text { the beginning, middle } \\
\text { and end }\end{array}$ & $\begin{array}{l}\text { Have a clear beginning, } \\
\text { middle and end }\end{array}$ & $\begin{array}{l}\text { Flow smoothly, from the } \\
\text { beginning to the middle } \\
\text { and then to the end. }\end{array}$ \\
\hline & $\begin{array}{l}\text { Irrelevant ideas and } \\
\text { details, no paragraph } \\
\text { structure }\end{array}$ & $\begin{array}{l}\text { Contains ideas and } \\
\text { details that are } \\
\text { somewhat related to the } \\
\text { paragraph }\end{array}$ & $\begin{array}{l}\text { Sentences are linked } \\
\text { together in paragraphs }\end{array}$ & $\begin{array}{l}\text { Sentences are clearly } \\
\text { organized in paragraphs }\end{array}$ \\
\hline \multirow[t]{2}{*}{ Convention } & $\begin{array}{l}\text { Several grammar, } \\
\text { spelling and punctuation } \\
\text { errors or omissions }\end{array}$ & $\begin{array}{l}\text { Several minor grammar, } \\
\text { spelling or punctuation } \\
\text { errors and omissions }\end{array}$ & $\begin{array}{l}\text { Only a few grammar, } \\
\text { spelling or punctuation } \\
\text { errors or omissions }\end{array}$ & $\begin{array}{l}\text { Practically no grammar, } \\
\text { spelling or punctuation } \\
\text { errors or omissions }\end{array}$ \\
\hline & $\begin{array}{l}\text { Unsatisfactory visual } \\
\text { presentation }\end{array}$ & $\begin{array}{l}\text { Satisfactory visual } \\
\text { presentation }\end{array}$ & Good visual presentation & $\begin{array}{l}\text { Excellent visual } \\
\text { presentation }\end{array}$ \\
\hline
\end{tabular}

The technique used by researchers to analyse data in this research are qualitative and quantitative technique. In qualitative technique, the researchers analyse data through open-ended questionnaires because the questionnaires consist of students' feeling, opinion, and perception about the situation in teaching-learning process. In quantitative technique, the researchers analyse data through writing tests, by getting the average score of each writing test I and writing test II compared to pre-writing test through the formula and scoring rubric below. The formula used to calculate the average score is:

In which:

$$
\underline{x}=\frac{\Sigma x}{N}
$$

$x \quad=$ The mean score in the pre-writing test, writing

test I, and writing test II

$\mathrm{N}=$ the number of samples

\section{Results}

\subsection{Quantitative Data}

This research was conducted in two cycles, and it was found that students' writing potential improved in cycle 2 . This can be seen from the indicators of the pantomime video by using the WH-Questions method that was successfully used. The first writing test (Pre-writing test) was done to obtain the students' genuine writing skills for narrative text writing before applying the WH-Questions method through pantomime video.

Table 2. Pre-writing Test, Cycle I and Cycle II Scores

\begin{tabular}{lllll}
\hline No & Participant & Pre-test & Test 1 & Test 2 \\
\hline 1 & A1 & 68,2 & 76,3 & 90,2 \\
2 & A2 & 49.1 & 50.0 & 76,5 \\
3 & A3 & 56.6 & 68.3 & 87,7 \\
4 & A4 & 43.8 & 49.7 & 90,2
\end{tabular}




\begin{tabular}{lllll}
5 & A5 & 44.6 & 50.0 & 76,5 \\
6 & A6 & 47.6 & 50.0 & 76,5 \\
7 & A7 & 62.3 & 72.8 & 91,2 \\
8 & A8 & 70.1 & 71.0 & 100,0 \\
9 & B1 & 45.5 & 50.0 & 76,5 \\
10 & B2 & 47.7 & 49.5 & 76,5 \\
11 & B3 & 41.9 & 50.0 & 76,5 \\
12 & C1 & 49.2 & 50.0 & 76,5 \\
13 & D1 & 73.5 & 77.3 & 99,7 \\
14 & D2 & 41.0 & 50.0 & 76,5 \\
15 & D3 & 46.0 & 50.0 & 76,5 \\
16 & D4 & 46.3 & 50.0 & 76,5 \\
17 & D5 & 46.8 & 50.0 & 92,7 \\
18 & F1 & 46.6 & 50.0 & 92,7 \\
19 & G1 & 60.0 & 71.8 & 90,2 \\
20 & I1 & 43.6 & 50.0 & 100,0 \\
21 & I2 & 40.5 & 50.0 & 76,5 \\
22 & M1 & 46.7 & 50.5 & 87,7 \\
23 & M2 & 46.9 & 50.0 & 76,5 \\
24 & M3 & 46.5 & 50.0 & 87.7 \\
25 & M4 & 48.6 & 51.0 & 75.0 \\
26 & N1 & 46.6 & 50.0 & 76.5 \\
27 & N2 & 46.2 & 50.0 & 76.5 \\
28 & N3 & 60.5 & 63.3 & 92.7 \\
29 & N4 & 46.6 & 50.0 & 76.5 \\
30 & P1 & 46.5 & 50.0 & 77.5 \\
\hline & & & & \\
10.5 \\
10.0
\end{tabular}

The students' score was calculated as follows:

Pre-writing test score:

$$
\underline{x}=\frac{\Sigma x}{N}=\frac{1893,5}{38}=49,8
$$

In which:

$\underline{x}=$ mean of pre-writing test

$\mathrm{N}=$ numbers of samples

In the second writing test (Writing test I) in the first cycle, the researchers found that most students could not write narrative text well. The reason was that the students' found it hard to start writing and to brainstorm to get the appropriate ideas. Furthermore, students still did not have a good grasp of grammatical patterns when arranging their text. It turned out that researchers still found grammatical errors in their writing. To overcome this problem, the researcher planned to guide the students by giving WHQuestions to ease their brainstorming to find the ideas. Students were also required to remember the narrative text structure and intrinsic elements to have better writing skills. Finally, the researcher assisted students in writing after watching the pantomime video.

After the researcher has applied that method, the researchers re-conduct the cycle 1 test resulting in better results. The calculation of the results are as follows:

Writing test, I Score (Cycle I):

$\underline{x}=\frac{\Sigma x}{N}=\frac{2095}{38}=55,1$

In which:

$\underline{x}=$ mean of cycle one score

$\mathrm{N}=$ number of samples

Then, the third writing test (Writing test II) in the second cycle showed that the mean score of students' writing narrative text also increased. The results calculation are as follows:

Writing test II Score (Cycle II):

$$
\underline{x}=\frac{\Sigma y}{N}=\frac{3161}{38}=83,2
$$

In which:

$\underline{x}=$ mean of Cycle 2 scores

$\overline{\mathrm{N}}=$ the number of samples

The final scores have greatly increased in the second cycle, showcasing the students' improvement from the first cycle. This result is and displayed in Figure 1. It shows that the average score calculated in test cycle 1 is higher than the average score in test cycle 2 .

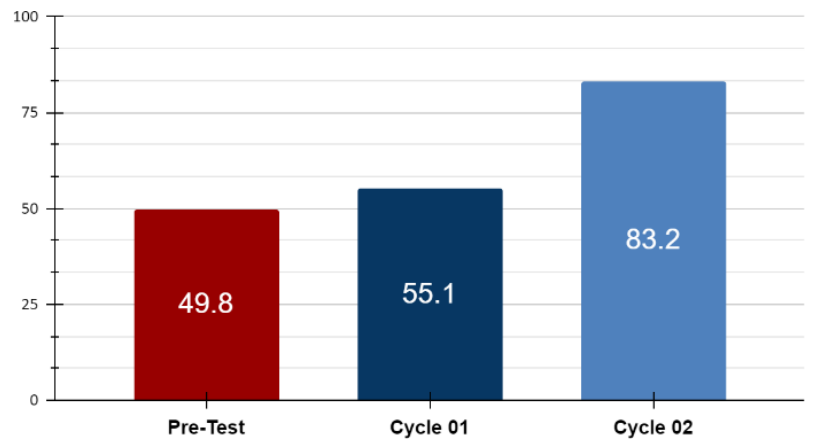

Figure 1. Students' Scoring Diagram

The graph showed the students' average score in each writing test improved. In the Pre-writing test, the total score reached 1893,5 with a average score 49,8 . Then, in the writing test I, the total score reached 2095.3 with a main score 55,1. The score was less significantly improved compared to writing test II with total score 3161.2 and main score 83.2.

These results showed an obvious improvement in students' narrative writing ability. Students who initially needed a lot of time writing now need less time to write their 
narratives. The students' significantly improved writing abilities are also shown by how they can provide more detailed information, students can afford to write longer paragraphs and provide sufficient supporting details, students can afford to organize their stories from beginning to the end, students can afford to complete their stories before the given deadline, students can afford to create variously better ways to start a story, students can afford to create variously better to understand grammar better than before, in which they became more cautious in constructing past sentences and capable to correctly recognize the conjugation verbs as well as to use vocabulary appropriately. In short, students were able to write narrative text very well.

\subsection{Qualitative Data}

To find the problems in SMK Swasta Imelda Medan, the researchers conducted pre-writing test for tenth-grade computer network engineering (X TKJ1) students. The problems found by the researchers were students needed much time to generate an idea for writing, students didn't really understand writing narrative text for the example the generic structure and the language features of the text, and students had many grammatical mistakes. Those problems should be solved and students' writing skill should be improved by implementing a teaching method which were by WH-Questions method through pantomime video. The target of this research was the improvement of students' writing skill especially in generating ideas and organizing text.

\subsubsection{Plan}

After finding the problems by the pre-writing test, the researchers made a plan to teach writing class by preparing materials such as explanation video about narrative text, pantomime video titled "Mime First Love" with the duration about 4 minutes, and WH-Questions instruction to prepare for the writing test I.

\subsubsection{Action}

The researchers implemented the teaching method starting by sending the explanation video about narrative text to the online class. Then the researchers posted the WHQuestions to guide the students in preparing the writing test I. The researchers also posted the pantomine video. The researchers then provided time for students to understand the narrative text explanation and for students who have questions about the lesson, ask the researchers directly via Whatsapp. After no question was given, the researchers then gave time for students to prepare for the writing test I until the next meeting. In the next meeting, students were given writing test I which was by writing down the narrative text in the pantomime video helped by the WH-Questions prepared.

\subsubsection{Observation}

Some students participated in this research well, even though at first, most of the students were late, some of the students didn't really pay attention to the video but then the students invite the other students creating a memorable moment.

\subsubsection{Reflection}

After analyzing the observation, the researchers found some improvement achieved by the students after doing the action. The mean score of the students was increasing, shown by the comparison of results in pre-writing test and writing test I. The mean score of the writing test I was 55,1. It was better than the mean score of pre-writing test which was 49,8 .

However, the researchers still identified some weaknesses in writing a story. Taking a long time to generate ideas and grammatical mistakes in tenses were the main problems faced by the students. Then the researchers planned to deepen the students' brainstorming skills by having a grammar exercise in the next meeting. The researchers then implemented the plan by giving a grammar exercise and planning to have writing test II which resulted in the significant improvement shown which the mean score of writing test II was increased by 28,1 . The mean score in writing test II resulted in 83,2 .

After all the lessons and writing test II ended, the researchers gave the open-ended questionnaires to the students about their experience, feeling, thought, etc. about the lesson given. Based on the questionnaires filled in by the tenth-grade computer network engineering (X TKJ1) of SMK Swasta Imelda Medan, the researchers found that there are $33,33 \%$ students found it very fun studying the lesson, $20 \%$ students finding it beneficial to study the lesson, $26,67 \%$ students being neutral about the lesson, $13,33 \%$ students finding it hard to understand the lesson, and 6,67\% students feeling very boring studying the lesson.

$17,65 \%$ students felt very interested studying by Zoom, $29,41 \%$ students finding it easy to understand studying by Zoom, 23,53\% students feeling fine studying by Zoom, $5,88 \%$ students feeling so-so studying by Zoom, and $23,53 \%$ students feeling and finding it very hard studying by Zoom.

Additionally, 50\% students felt very satisfied with the teaching-learning process, $18,75 \%$ students feeling satisfied with the teaching-learning process, $18,75 \%$ students feeling neutral with the teaching-learning process, and $12,5 \%$ students feeling dissatisfied with the teaching-learning process.

Moreover, 18,75\% students found the lesson very clear, $12,5 \%$ students having difficulty in English language, $18,75 \%$ students feeling poorly understand the lesson, $18,75 \%$ students having difficulty in analyzing the video, and $31,25 \%$ students finding the lesson very confusing.

There are 18,75 students who are able to make narrative text from studying in online class, $37,5 \%$ students getting slight knowledge about the lesson, 6,25\% students understanding about pantomime, $6,25 \%$ students able to understand the lesson better, and $31,25 \%$ getting nothing from the lesson. 
From the data above, it could be seen that most students find it very fun studying the lesson, easy to understand studying from zoom, very satisfied with the teachinglearning process, very confused about the lesson, and get slight knowledge about the lesson.

\section{Discussion}

Remembering the online teaching-learning process held in this pandemic era, teachers' role is very needed nowadays, where teachers are demanded to be able to use enthusiastically active and fun learning method to hook up students' interest in teaching-learning process. Because of that, researchers find out that watching pantomime video by Zoom is proven to improve students' enthusiasm in teachinglearning process. From one questionnaire filled in by the students, they state that teaching-learning method by using pantomime video make it feel as if they are watching a video with their friends. Thus, they do not want to miss that moment.

Compared to Deta (2018) who found the mean score compared in students' tests (pre-test and post-test) was only improved 13,5 points, this research was found out that the improvement between test in cycle I and cycle II was 28,1 points. The previous researchers conducted her research by using pantomime video directly in the class to improve descriptive writing skill, meanwhile, in this research the researchers conducted the research by using pantomime video in online learning by using Zoom to improve narrative writing skill. And both of the results showed a successful application. So, it can be concluded that teaching-learning method by using pantomime video can be applied directly in the class as well as in online learning. The method is very compatible to improve students' writing skill in narrative and descriptive text.

Compared to Puspitasari (2017), the teachers paid attention to the students' behavior in direct learning tends to be passive. in that situation, teachers were expected to provide regularly-good monitoring to students. That was known as teacher-centered learning approach, meanwhile, in this research, the researchers used the WH-Questions method and pantomime video as the media to raise enthusiasm in online learning, in which the teachers' roles were only as facilitator in the teaching-learning process. This was known as student-centered learning approach. Moreover, comparing to the situations and the score improvements, students-centered learning was considered successful in improving students' writing skills.

Overall, the research result appears that there were some improvements. From the findings, it showed the students' writing skill improvements. By conducting more exercise in writing through video, students' writing ability had improved. They can afford to get ideas and give sufficient details. They can afford to organize the text structure from the orientation, complication to the resolution clearly, and they were able to connect ideas as well as details with the text.
The video contained a love story similarly relatable with the student's love life making the students easily write the text. Besides, the students could make sure that they used the appropriate tense in their writing. Additionally, the students could widen their vocabulary in describing the action of the mimes in pantomime video. The test results also showed good improvements, in which the average score in the end of cycle 2 was 83.2. It increased 28.1 points from the average score at the end of cycle 1 . It could be stated that there was an improvement in students' writing ability.

\section{Conclusion}

After doing the classroom action research in two cycles, it can be concluded that the use of WH-questions method through pantomime video had been effective and had successfully improved the students' writing ability of narrative text. The usage of pantomime video encourages the students to creative in learning and increase their imaginative level. Moreover, this unique type of video will allow teachers to detect the extend of the student's vocabulary mastery, how the students pour their idea to the text with their own language, improve students' critical thinking skill by identifying movement into language, and it will a novel media that support teachers to increase students' motivation and engagement which has been at low levels during the Covid-19 online learning. Future studies should look into more unique types of media or develop much more innovate media in order to address the serious issue of low learning motivation caused by the pandemic.

\section{References}

Aubert, C. (2005). Arts of Pantomime. Henry Holt and Company.

Burns, A. (1999). Collaborative Action Research for English Language Teachers. Cambridge University Press.

Derwianka, B. (1995). Exploring How Texts Works. Australia Print Group.

Deta, M. (2018). The Use of Pantomime Video in Teaching Writing descriptive text in SMAN 1 Siantar. Jurnal Pendidikan dan Pembelajaran Khatulistiwa, 7(9).

Edge, J. (1993). Essentials of English Language Teaching. Longman.

Harmer, J. (2001). The Practice of English Language Teaching (3rd Edition). Longman Group Ltd.

Hopkins, D. (1985). A teacher's guide to classroom research. Open University Press.

Junaidi, J., Hamuddin, B., Julita, K., Rahman, F., \& Derin, T. (2020). Artificial Intelligence in EFL Context: Rising Students' Speaking Performance with Lyra Virtual Assistance. International Journal of Advanced Science and Technology Rehabilitation, 29(5), 6735-6741. 
Kemmis, S., \& McTaggart, R. (1988). The Action Research Planner. Deakin University Press.

Puspitasari, H. (2017). Improving Students' Narrative Writing by Using WH-question AS A Guide. Jurnal Pendidikan dan Pembelajaran Untan, 6(11).

Raharja, E. S. (2016). The Use of Pantomime Video in Teaching Narrative Paragraph Writing. Jurnal Pendidikan dan Pembelajaran Khatulistiwa 5(3).

Rahim, M. N. (2019). The Use of Blended Learning Approach In EFL Education. International Journal of Engineering and Advanced Technology, 8(5), 11651168.

Richards, J. C., \& Renandya, W. A. (2002). Methodology in Language Teaching: An Anthology of Current Practice. Cambridge University Press.

Syafiq, A. N., Rahmawati, A., Anwari, A., \& Oktaviana, T. (2021). Increasing Speaking Skill through YouTube Video as English Learning Material during Online Learning in Pandemic Covid-19. Elsya : Journal of English Language Studies, 3(1), 50-55. https://doi.org/10.31849/elsya.v3i1.6206

Yudar, R. S., Aditomo, D. T., \& Silalahi, N. S. (2020). Movie as a Helper for Students' Pronunciation in Speaking Skill Class. Elsya: Journal of English Language Studies, 2(1), 15-19. 